\title{
Contestation for land towards Kampong Adat of Sakai Minas in Riau
}

\author{
Istiqomah Marfuah', Muhammad Rawa El Amady2* \\ ${ }^{1}$ Asosiasi Antropologi Indonesia (AAI) Province Riau. Indonesia. \\ ${ }^{2}$ Postgraduate Sociology, Faculty of Social and Political Sciences. Riau University, Indonesia.
}

*Correspondence author: mrawaelamady@gmail.com

\begin{tabular}{|c|c|}
\hline ARTICLE INFO & ABSTRACT \\
\hline $\begin{array}{l}\text { How to cite: } \\
\text { Marfuah, I., Amady, } \\
\text { M.R.E. (2021). } \\
\text { Contestation for land } \\
\text { towards Kampong Adat of } \\
\text { Sakai Minas in Riau. } \\
\text { ETNOSIA: Jurnal } \\
\text { Etnografi Indonesia. 6(2), } \\
252 \text { - 264. } \\
\text { DOI: } \\
\text { 10.31947/etnosia.v6i2.18545 }\end{array}$ & $\begin{array}{l}\text { This research discussed the Kampong Adat in Minas Barat Village, } \\
\text { Minas District, Siak Regency. Regional Regulation Number } 2 \\
\text { concerning the determination of Kampong Adat had issued since } 2015 \text {. } \\
\text { However, the completeness of requirements for the Ministry of Home } \\
\text { Affairs approval has not been completed until November 2021. This } \\
\text { study used an ethnography design; the researcher lived in the research } \\
\text { site for two months. The data were collected by participatory } \\
\text { observation, in-depth interviews with selected informants due to their } \\
\text { knowledge and experience in the establishment of Kampong Adat. The } \\
\text { data were analyzed descriptively by discussing with theory and } \\
\text { resulted in the general trend as this research's findings. This research } \\
\text { found, first, Since Minas Barat Village of determined as Kampong } \\
\text { Adat, the community of Sakai Tribe have been minority citizen. } \\
\text { Second, the Sakai community has some difficulties preparing the } \\
\text { complete requirements for approval of the Ministry of Home Affairs } \\
\text { because there are many interests involved in the village. Third, the } \\
\text { government has not given severe attempts for Kampong Adat. The } \\
\text { government let the completeness of approval has not yet been fulfilled } \\
\text { for almost seven years. This study contributed to the anthropology of } \\
\text { policy, specifically for indigenous peoples, in issuing affirmative } \\
\text { policies to fulfill the rights of indigenous peoples. }\end{array}$ \\
\hline
\end{tabular}

\section{Introduction}

Kampong ${ }^{1}$ Adat in Siak Regency, Riau Islands is a product of Regional Regulations (Perda) the Government of Siak Regency Number 2 years 2015 d ratified January 15. This regional regulation aims to revive the role of traditional leaders in administering government, developing and maintaining their customs. The focus of this regulation is

\footnotetext{
1 The term village in the Government of Siak Regency is a substitute term for the term village, conceptually the term Village of with a different village should be. Based on the Regional Regulations Number 1 Year 2015 regarding the change in the naming of the village to Village of as well as several other related regulations
} 
affirmative policy for local communities to fill positions of village government. Through this Regional Regulation, positions in the village government are filled by community members who meet customary requirements based on the kinship system that applies to Kampong. The reason for the formation of Kampong Adat is the concern about the loss of tradition due to the large urbanization in Siak Regency. Romadhon, et al. (2018) stated that the existence of Kampong Adat is influenced by the dynamics of development that can weaken and even eliminate community local customs. This Regional Regulations stipulates 8 Kampong Adat in Siak Regency, ${ }^{2}$ Previously it was a Village of which changed its status to a Kampong Adat (Setiawan \& Zetra, 2018).

Village of Minas Barat stipulated as Kampong Adat because it has the special characteristics of Sakai Village, be conducted by Batin Limo Boban Mineh. Sakai in Village of Minas resides in two main locations, namely first, in Minas Origin or also known as Batu Bosa which is the early Village of of the Sakai people in Minas as the forerunner Village of Minas Barat; second, in the Sakai alley on the side of the road Pekanbaru - Duri. The Sakai people who live in the Sakai alley are a relocation program for the Sakai tribe through the Isolated Community Development Program (PMT) Year 1977 (Interview by Datuk Boban Mineh, August 19, 2021).

Village of Minas Barat is a sub-urban city of Minas which is the administrative center of PT Chevron, presently PT PHR. PT Chevron itself is already present in Minas Barat since 1942 marked by the first oil well of 6000 active and inactive oil wells are here (Purba, 2011). Besides, that Village of Minas Barat also present forestry industry companies (HTI) PT Arara Abadi, and surrounded by oil palm plantations, both community oil palm plantations and those belonging to oil palm companies PT. Teguh Karsa Wanalestari (TKWL) and Sekato Jaya Lestari Cooperative3 ${ }^{3}$

Village of Minas Barat very heterogeneous, various tribes are there. The population is the Sakai tribe as much as 30\%, Batak 30\%, Minangkabau 15\%, Java 15\% and Nias $10 \%$ of the 5,716 inhabitants (BPS Siak, 2021). Cultural characteristics, customs are no longer prominent in Minas Barat. Village of Governance and Village of Deliberation Affairs which led by indigenou people of Sakai. Village of Minas Barat historically the indigenous people who control the forest and land in the Landscape Minas, led by Batin Limo4 Boban Mineh appointed by the King of Siak.

Referring to the concept for Kampong Adat in the Village Law Number 6 Year 2014 that regions are given the space to form a government that is in accordance with the characteristics of local culture. Village of Minas Barat in contact with Village Law Number 6 Year 2014 on the characteristics of the Sakai customary law community, and the Siak royal government system. This Regional Regulations gives the Sakai tribe an

\footnotetext{
2 There are eight villages that have been determined through Regional Regulation Number 2 Year 2015 are: Lubuk Jering, Village of Tengah, Kualo Gasib, Asli Anak Rawa Penyengat, Sakai Minas Barat, Sakai Mandi Angin, Sakai Bekalar, and Adat Sakai Libo Jaya

3 Google Map, 2021, https://goo.gl/maps/BzfwGiDWBwrSdD8aA, Downloaded October 12, 2021, information on the whereabouts of bus companies was detected via google map, this effort was made because no other information was available about information on companies operating in Minas Barat.

${ }^{4}$ Batin Boban Limo is datuk pucuk or the leader of the four minds in Siak Regency, namely Bantin Sam-sam, Batin Belutu, Bomban Sri Pauh, dan Batin Beringin.
} 
affirmative right to lead the village government in Minas Barat, and the use of office terms that apply to the Siak Kingdom and the Malay Customary Institution (LAM). This practice is certainly different from the concept of a Kampong Adat as conveyed by Gunawan (2013) that a Kampong Adat is a village that implements the rules of religious law or traditions or customs that apply in their respective territories. It is also different from the practice of Kampong Adat in Bali as reported by Gede (2016) that Kampong Adat in Bali have specific characteristics, namely tourist villages with dominant Balinese culture and customs. The community is governed by customary law alliances in everyday life, customary government carries out customary functions. Village administration affairs are regulated and carried out by the village government.

Substantially, the formation of 8 villages in Siak Regency, especially in Kampong of Minas Barat does not overhaul the village governance structure as regulated in Village Law Number 6 of 2014. The government structure and governance are not regulated in Regional Regulation Number 2 of 2015, everything is still in the hands of the Headman.

This Regional Regulation only regulates the replacement of the mention of the term from the term village to Kampong Adat with the specific that in Kampong Adat In this case, a customary institution must be formed which is tasked with verifying the prospective Headman ${ }^{5}$ like MPR. The position of the head of the Kampong Adat of leader is not necessarily led by the inner Sakai, as well as the BAPEKAM (Kampong Representative Body - a replacement for the term BPD, Kampong Representative Affairs) still exists. The inner position is in the customary institutions that determine who is worthy of being a potential leader. For the process of selecting the Headman, candidates who pass the verification will be selected through the village of election. In terms of government administration, it is still carried out by the village government and the implementation of customary functions is carried out by traditional institutions (Interview, Bathin Limo, September 2021).

The breakthrough of the Kampong Adat of in Siak Regency is a concrete form of the government's efforts to welcome the movement for the recognition and protection of indigenous peoples. In accordance with the mandate in the explanation of Article 18 Year 1945 Constitution, then in the UUPA Number 5 Year 1960, in Article 2 (4) the state's control rights above can be exercised delegated to autonomous regions and customary law communities. In Riau the protection of indigenous peoples was initiated by the Kampar government through Regional Regulation Number 12 Year 1999 concerning Ulayat Land Rights and in Riau Province Government issued Regional Regulation Number 14 Year 2018 concerning Recognition of the Existence of Customary Law Communities and Environmental Protection and Management (Rahayu, 2013)

After 7 years being ratified by Regional Regulation Number 2 Year 2015, Village of Minas Barat have not been able to carry out the function of Kampong Adat of because it has not been ratified by the Ministry of Home Affairs (Kemendagri). Kampong Adat Minas Barat have not completed the requirements as stipulated in the Regulation of the Minister of

${ }^{5}$ Headman is a term for village heads in the Siak kingdom, which is now used again to replace the term village head. 
Home Affairs Number 52 Year 2014 to become a Kampong Adat Article 5 paragraph 2, especially in paragraph 2 article 5, which covers a). the history of the Indigenous Law Community; b). Indigenous territory; c). customary law; d). assets and/or customary objects; and e). customary government institutions/systems. To fulfill the requirements of paragraph 2 article 5 Year 2014 Minister of Home Affairs Regulation, the community interacts with various parties, such as claims to administrative areas from neighboring Village of to the Sakai Minas customary area, company concession areas, control of customary law and customary objects.

Logically, the submission of a customary village is determined by the district government after it is submitted by the village government with the final completeness. However, uniquely in determining the customary village in Siak Regency, the government and DPRD ratify Kampong Adat that do not yet have the complete requirements for Kampong Adat. There is also no local regulation that regulates customary village governance. The district government just issued a Regent Regulation (Perbup) regarding Kampong Adat of in 2017, then the provincial government issued Regional Regulation Number 2 Year 2019 Institutional Structure, Filling of Positions and Term of Office of the Kampong Adat Head, five years after the Kampong Adat of Regional Regulation was ratified by the DPRD of Siak.

This phenomenon suggests that the district and provincial governments are dualistic towards the implementation of Kampong Adat. The government has formally ratified the Village of Indigenous Regional Regulations before pushing for a legal basis at the provincial level and the preparation of equipment at the Village of level. In fact, there is a crucial point in fulfilling the requirements of a Kampong Adat, namely the mapping of customary areas. Mapping of customary areas will come into contact with various parties because it involves the interests of various parties, giving rise to contestation on the recognition of customary areas.

The contestation is something described by Vancil, (1993) as differences and disagreements over a thing or resource, which triggers pros and cons, a competing circle of values, facts and policies of conflicting arguments. In relation to the endorsement in Kampong Adat Minas barat, Then opinion by Afrizal (2012) it becomes relevant that there has been a contestation of space in Indonesian society, especially the struggle for land between indigenous peoples and businessmen. The patterns of contestation of space in the struggle for land between customary law communities and businessmen. Asrida, et al. (2018) stated that there are two forms of power that affect the contestation of customary land space, namely formal power (visible power), namely the policymaking process and hidden power which illegally seizes customary land space. Both formal power and hidden power are behind businessmen to win the contestation for customary land space. The support comes from local, national and global levels.

Regional Regulation Number 2 Year 2015 stipulates 8 Kampong Adat in Siak Regency, including: Kampong Adat Minas Barat has not yet received approval from the Ministry of Home Affairs until December 2021. This study builds the assumption that the delay in the ratification of Kampong Adat of in Siak, in particular of Village of Minas Barat because of the contestation between the Sakai customary law community and 
businessmen, where the government supports businessmen in secret. Formally, the government of Siak Regency and Riau Province supports customary law communities by issuing Regional Regulation Number 2 Year 2015, but secretly the government sided with businessmen. This phenomenon is of interest to researchers so this is a strong reason for us to research this theme.

\section{Methods}

This research is qualitative research, using ethnographic method. Researcher's relationship with batin Kampong Limo in Minas Barat since 2013 through mentoring activities for Batin Limo in resolving conflicts between the Sakai Batin Limo community and the company in Minas Asal. The closeness of the researcher with the leaders of the Sakai community has been well established, so that the daily lives of the Sakai people have become an inseparable part of the research activities for more than 8 years. For this study, two stages were carried out, first, the data was taken by students for 50 days from August 11 to September 20, 2021, who lived in the village, recording all relevant information, second, the research was continued by the researcher for two weeks back to the village. Minas Barat, specially to Minas Asal stayed in Minas Asal to communicate intensely with Batin Limo and community leaders, from September 24 - October 10, 2021.

Researchers conducted a library study by visiting several libraries in Pekanbaru and looking for information via the internet as initial data. The results of the library study are used as the starting material to guide the information found in the field. After that, through the results of the first research, the researcher deepened the data by discussing it with theory and then going to the field in the field in Kampong of Minas Barat, Minas District, Siak Regency. Researchers conducted observations involving in- depth interviews, village observations, agricultural activities carried out by Sakai entrepreneurs, community social activities and directed discussions with informants and local village communities.

The data taken are village profiling, history of formation in Kampong Adat Minas Barat, the activity of preparing the completeness of the requirements for approval from the Ministry of Home Affairs. The data were obtained apart from the results of the observations involved, the researchers also conducted in-depth interviews with Batin Limo, Headman, Bapekam administrators and Sakai Customary Institutions. All results of observations, discussions and each interview were written in the form of field notes.

Data processing is done by using descriptive analysis method. There areseveral stages to carry out data analysis, namely: first, the data is arranged systematically and then the results from field notes, interview transcripts, and references to some secondary data are also analyzed holistically. Second, researchers pay attention to the relationship between one data and another to obtain a general pattern. Third, the data is built by considering, reviewing, and discussing the theory written in the research reports. 


\section{Results and discussions}

\section{- Long way back to traditions}

Batin Limo describes his mood towards the current condition of the Sakai community, as follows;

"When I visited several villages in Java, I saw that the Javanese people had very close social relations. They help each other, for example at a party, they help each other bring ingredients from home to a party in the form of rice, chicken, eggs, sugar and others in turn. The atmosphere is different from that in Sakai society, when people come to parties with money. Bringing cooking ingredients is more helpful than carrying money, because money is not worth much. That's why, after I came back from Java, I invited Batin Belutu, Batin Rantau Bertuah and Batin Mandiangin to tie up social relations at least through the party." (Interview, Datuk Boban Manieh, Batin Limo, September 27, 2021).

Boban Mineh Bonsu which is often called Batin Limo which is a bud batin who oversees the five kebatinan, sees that the problems faced by the entire Sakai Tribe are getting more complicated, in particular Batin Limo in Minas Barat. The first step to take Batin Limo is to build the fifth inner communication in Siak Regency to strengthen relationships with others inner.

"I started contacting Batin Belutu, Batin Tengganau and other batin to talk about this traditional issue." (Interview, Datuk Boban Manieh, September 27,2021)

Communication with the inner and other traditional apparatus was originally built to revive the Sakai customs and to strengthen social relations among the Sakai people. Batin Limo invites other minds and the Sakai community to always communicate if an event occurs or activities will be held such as a wedding party, an accident occurs, and so on. In addition, Batin Limo began to invite these minds to retrace the history of Sakai in their respective regions and the customs that are still being carried out.

This expression of Inner Limo's mood is a culmination point of the anxiety of the Sakai community leaders towards the swift currents of change that have occurred in the Sakai Batin Limo community. His childhood memory resurfaced when he saw the cohesiveness of the people he met in other places, but he no longer found them in the Limo inner custom area. This complaint, of course, stems from the change from agrarian ecology to urban ecology, the dense population, the entry of a broad market economy system. The Sakai tribe previously lived in an agrarian rural ecology with a strict, familial and communal social system (Amady, 2014). Inner and traditional elders also miss their role as inner and traditional leaders which are getting lost. Moreover, there has been a change in agricultural activities from shifting cultivation to oil palm farmers, who no longer practice ancestral traditions, such as tuluk-tuluk (gotong royong). Batin longs for a communal atmosphere in the midst of widespread individualism.

Batin Limo anxiety is understandable because the Sakai residents are a minority in their own Kampong. The number of Sakai residents is only 30\%, while 70\% are immigrants 6 .

\footnotetext{
${ }^{6}$ Since 1942 the Inner Limo customary area has entered the oil industry of PT. CPI(later changed its last names to PT. Chevron), until now it has switched to PT. Pertamina Hulu Rokan (PHR). The presence of this oil
} 
The amount of $30 \%$ was obtained after all children resulting from marriages between Sakai residents and immigrants were included as Sakai residents without considering the matrilineal kinship system, which was adopted by the Sakai Tribe. If a man marries a woman outside the Sakai tribe, the children resulting from the marriage of a Sakai man with an immigrant are not included as Sakai residents, so the percentage of Sakai residents is only estimated at 10 percent, because in 2015 the number of Sakai residents was only $8 \%$ of the total population of Kampong. Minas Barat (Interview with Datuk Boban Manieh, September 30, 2021). Limo's inner restlessness is getting more and more place after the reformation. Not only is the space for expression more open, reform has also opened up space for indigenous and indigenous peoples' access to companies and government. 7

After the reformation, the Sakai tribe formed several organizations including Gapensus which covers the whole mind, as well as the Sakai Putra Putri Communication Forum (FKPPS), the Sakai Student Youth Association (HPPMS) and the Sakai-Minas Kerapat Tradition Council (MKA) and the Riau Sakai Traditional Institute after 2016. Through these organizations, Sakai leaders get a place to interact directly with various parties, especially the government and companies operating in the territorial area of the Sakai customary land forest area, where the idea of returning to tradition is an important issue that is always voiced.

Inner Limo's efforts have found a place with the issuance of Law Number 6 Year 2014 concerning Villages. Through this law, indigenous peoples have the opportunity to obtain their rights through the establishment of customary villages. the determination of a customary village requires the conditions stipulated in the Minister of Home Affairs Regulation Number 52 Year 2014. To be designated as a customary village, Article 5 paragraph 2 states the conditions, namely a.) the history of the Customary Law Community; b) Customary territory; c) Customary law; d) assets and/or customary objects; and e) customary government institutions/systems (Zain \& Siddiq, 2015).

company led to the arrival of many workers from outside Riau, such as from West Sumatra, North Sumatra, Nias, and the island of Java. In the 1980s, a forestry company began operating which had a HPH (Forest Utilization Rights) permit by PT. ETC in Minas Area. In 1996 another forestry company operated, Industrial Plantation Forest (HTI), namely PT. Arara Abadi, West Minas which was included in the operational area of PT. AA in the Wave district based on the Decree of the Minister of Forestry Number 743/Kpts-II/1996. Apart from PT. AA, there is also a PT. Riau Abadi Lestari (RAL) concession. These two HTI companies are wood suppliers to PT. Indahkiat Pulp and Paper (IKPP) which operates in Perawang. The presence ofthis HTI causes agricultural fields, plantations, forests, water sources and even their homes to disappear. Almost 50 species of flora and 20 faunas have become extinct since HTI started operating. The eviction of houses and gardens occurred in Batu Bosa Hamlet in 2012 (Marfuah, 2014).

${ }^{7}$ Since the reformation of PT. CPI (Chevron Pacific Indonesia) has started to provide labor- intensive programs in its working area, not only specifically for the Sakai tribe. The Sakai tribe, whose education is still very limited, can access this program. PT CPI in 2003 made a program to grow local entrepreneurs known as LBD (Local Business Development). A program intended for all entrepreneurs in the CPI working area. (Interview with the Chairman of Gapensus, Mus Mulyadi, August 2021). PT CPI, through Deswandi, CPI employees held a meeting with representatives of Sakai residents represented by Bagindo, Tarmizi, and H. Bastian to discuss opportunities for Sakai residents to be involved in the LBD program. At this meeting, theGapensus (Sakai Entrepreneurs Association) was formed whose members consist of eight companies, the company being created by PT CPI and chaired by Tharmizi. These companies get projects with a direct point of view system, especially labor-intensive projects, cleaning sewers, cutting grass and others. Then, in 2007 Gapensus was formed in the same way in Duri and other minds. (Interview, Masury, Chairman of Gapensus, 2021) 
The Sakai Tribe especially inwardly gets information about Law Number 6 Year 2014 and Regulation of the Minister of Home Affairs Number 52 Year 2014 easily through meetings with various government parties, companies, non-governmental organizations (NGOs), especially Riau Malay traditional institutions which were established to the villages in the 2012s. In the Sakai community, the Sakai Malay Customary Institution was established which covers the entire inner self in Sakai and is established every Village of Sakai. (Interview, August 2021)

The Sakai Malay Tradition Institute and the Riau Siak Malay Tradition Institute encourage and fight for a return to tradition. The Siak Regency Government responded by including four of the eight Kampong Adat, namely Kampong Adat Sakai, namely Minas Barat, Sakai Mandi Angin, Sakai Bekalar, and Tradition Sakai Libo Jaya. Four inner Sakai become Kampong Adat. Thus, the portion of tradition institutions has a special place in chapter VI, three articles, plus article 13 which involves LAMR (Riau Malay Tradition Institution). This Regional Regulation is a door for the Sakai Tribe to re-enter their home, return to childhood memories, rebuild the social and cultural life of the Sakai people in a changed ecology.

\section{- Contestation of Interests in Kampong Adat}

Regional Regulation Number 2 Year 2015 which stipulates eight Kampong Adat, one of which is Kampong Adat Sakai Minas Barat, one of the other four of Kampong Adat Sakai cannot be legalized as Kampong Adat because it has not been authorized by the Ministry of Home Affairs through village code number/Kampong Adat. Alkadafi, (2019) reported the results of his research that the determination of eight Villages of being Kampong Adat in Siak Regency has not been studied comprehensively, so the policy has not been followed by the fulfillment of the requirements as stipulated by the Law so that it has not been able to get a registaration number from the Governor of Riau and the Kampong Adat code of the Ministry of Home Affairs.

In line with Alkadfi opinion above, Prakoso, et al (2020) said that there are two obstacles to implementing the requirements from the central government, first, the lack of reflection of the Kampong Adat concept that once existed in Siak Regency, the old tradition figures have died so that traditional documentation The village that once existed is hard to come by. Second, the lack of knowledge of government officials about Kampong Adat. In addition, according to the author, in the Kampong Minas Barat community, the third is still constrained by boundary disputes between Minas Barang and Kampong Godang, where an agreement on boundary demarcation has not been reached. Fourth, the Village of West Minas is based on village administration, which could be in the village not only in the Inner Limo area, so that the Village of map and the traditional area map referred to by different ministries may even coincide. This could also be the sumir of the equipment prepared by Limo's mind.

The opinion above is reinforced by the opinion of Agustina Panca (Alkadafi, 2019) that the problems of determining the Kampong Adat are as follows; First, data collection on tradition tradition cannot be carried out optimally because tradition figures in the Kampong of have moved or died; Second, the Village of has been filled by the majority 
of immigrants so that norms, traditions, traditions, culture and Kampong laws are difficult to apply so that they are almost extinct. Third, the Village of Tradition Density Council has not maximally explored the Kampong and Adat. Fourth, an agreement has not been made between tradition figures and law enforcers on the boundaries of the enforcement area by state law enforcers and tradition law enforcers. Fifth, there has been no Adat decision and agreement with immigrants whether traditional law also applies to immigrants. Sixth, the Riau provincial government has not yet issued a Regional Regulation or Pergub concerning Kampong Adat so that it becomes an obstacle for the district government to make further regulations in the form of a regent's regulation to regulate Kampong Adat, thus causing uncertainty about the institutional structure, filling positions and the term of office of the Kampong Adat Headman. Added by Haryono, (2017) that studies on Kampong Adat that are in accordance with the origins that apply in Siak Regency are still very limited, and the knowledge of the Siak Regency Government apparatus about Kampong Adat is still limited, especially socialization about Regional Regulation Number 2 Year 2015 is still limited.

The findings of the field data strengthen the results of the study above, first, the elite of the Sakai Batin Limo has business relationships with all companies operating in the Batin Limo area. On the other hand, important figures in preparing the equipment to get the approval of Kampong Adat from the ministry are also the same elite. Referring to the opinion of Afrizal and Asrida, et al above that in the contestation for traditional land space there is hidden power, which is at the village, sub-district, district, provincial and global levels. For almost 8 years, the preparation of Kampong Adat equipment has only been carried out once a year. The slow pace of preparation of the equipment is a strong indication that there is a hidden involvement of power at all levels to slow down the implementation of Kampong Adat Minas Barat.

According to Lontai and Jiran (Interview October 5, 2021) that since it was designated as a Kampong Adat in January 2015, tradition figures hold a meeting once a year to discuss tradition rules, history and inventory of any remaining tradition heritage. The results of these meetings have determined the structure of the Sakai Minas Tradition Institution, the leadership of the tradition institution includes the mind, the spiritual representative, the stick and there is the dubalang (guardian of security and order). In each hamlet there is a tradition holder, this tradition holder plays a role in ensuring the existing rules run well in their respective areas and solving community problems in their respective areas. However, the Kampong Minas Barat does not yet have tradition rules which are legalized as legal products by the Kampong government. Until this research was conducted, these regulations were still in the drafting stage, including what traditional legal subjects were in effect, and whether they also applied to immigrants had not yet been discussed in these meetings. Even the map of the tradition area has not been made because there are still parties who have not agreed on the determination of the boundaries.

According to Darius, Writer II of the Village of West Minas, since 2021, there have been intense meetings to prepare for the ratification of the Kampong Adat, since September a special meeting has been held involving the sub-district head to discuss the mapping of 
the wialaya tradition. 7 specifically for the discussion of traditional area maps and strategies for solving boundary problems. Present at the meeting were all leaders of tradition institutions, including representatives of LAMSiak and LAM of Minas District. All these meetings are funded by the Kampong fund, including the tradition area mapping fund. (Darius, Interview, 10 October 2021) Second, there are no complete documents to submit to the Ministry of Home Affairs. During the month of October, 2 meetings were held, but the meeting was still in the form of preparation to carry out mapping of the tradition area. Other documents concerning the tradition that will become the characteristics of Kampong Adat Sakai Batin Limo are not yet available, or have not been opened to the public. Each time discussing the completeness of the ratification of the West Minas Kampong Adat to the Ministry of Home Affairs, each figure stated that the document was in the hands of another tradition figure.

Third, there was a debate between the Riau Malay Tradition Institute and the Riau Sakai Tradition Institute about the tradition that became the basis of the rules used in the Kampong Adat. The Sakai community through the Riau Sakai Tradition Institute makes the Sakai tradition the basis for the rules in the Kampong Adat. Meanwhile, the Riau Malay Tradition Institute wants the Sakai tradition that is based on the Riau Malay tradition. This is also a contestation that needs to be resolved.

Fourth, as it is known that in West Minas 70\% of the population are immigrants, only $30 \%$ and only two areas that are fully populated by the Sakai Tribe, namely in Lorong Sakai and in Minas Origin. There is a contestation between the values of the Sakai tradition and the immigrant community. Is Kampong Adat Minas Barat only valid for the Sakai people, or for all residents. On the one hand, the legal basis for the tradition is the Sakai tradition, the Kampong government must be controlled by the Sakai people, on the other hand, the majority of the people are immigrants. Agreements between the Sakai people and immigrants have not yet been established.

The results of a study by Alkadafi, (2019) that in 2018 several Sakai Bekalar Kampong Adat even since their formation in 2015 to 2018 there have never been a meeting of customary leaders to discuss this Sakai Bekalar Kampong Adat. Although historically the Village of Bekalar is the Village of Sakai which was inhabited before independence, but now the number of Sakai residents is a very minority where the majority is filled with immigrants.

Fifth, formally, the government only issued Regional Regulations after 5 years since the issuance of Regional Regulation Number 2 concerning Kampong Adat of the Siak Government. The Riau Provincial Government issued Regional Regulation Number 2 of 2019 concerning Institutional Structure, Position Filling and Term of Office of Kampong Adat Heads, on July 4, 2019. (BPK RI, 2021). This Regional Regulation is the basis for Customary to register with the governor for approval from the Ministry of Home Affairs. Unfortunately, it has not been continued with the issuance of the Governor's Regulation regarding the tradition village. Three years earlier, the Siak Regional Government issued Siak Regent Regulation Number 95 of 2017 concerning the Authority of Village of and Kampong Adat based on origin rights and local authority at the Village of and Kampong Adat scale, on September 1, 2017. Kampong Adat. District Siak issues Regional Regulations but has not been able to follow up on technical regulations because the province has not provided legal 
instruments so that these Regional Regulations can be operational. On the other hand, Kampong Adat figures have not optimally formulated everything to meet the requirements of Kampong Adat.

This study finds that kampong adat are an effort to commodify Sakai Customs for personal gain. Village elites or tradition figures, districts and provinces commodify Kampong Adat for political and economic interests. These elites appear on two sides, one side is fighting for the affirmative politics of tradition law communities, on the other hand they use tradition to get economic resources and political support from companies. The company cannot refuse Kampong Adat decision because it is the absolute right of the government, but it could conspire to thwart the implementation of Kampong Adat.

Formal power utilizes the curative point of Kampong Adat registration requirements through mapping the tradition area. The Sakai tradition shops admit that there are many obstacles in making a map of the tradition area. The Head of Minas Hendra Sub- district (Interview, October 2021) admitted that there was a trade-off when it came to determining boundaries.

The company is very interested in determining the tradition area when the Kampong Adat is officially recognized by the Ministry of Home Affairs, it will open up opportunities for the tradition law community to reclaim the rights of the traditional community to the land managed by the company. This condition is estimated by the company will hamper the company's operations. Therefore, there is an opportunity for the company to influence the neighboring Kampong to reject the Kampong of boundary agreement and cooperate with hidden powers to hinder the mapping process.

In addition, from formal power, this research finds that first, efforts to form Kampong Adat seem to be political will, a form of affirmative policy for traditional legal communities. Political will that has not been accompanied by technical and legal readiness. The distance between the issuance of Regional Regulation Number 2 of 2015 and Perbup Number 95 Year 2017 took two years, the new provincial Regional Regulation issued 5 years. The Riau government should first make a Village Regulation and a Kampong Adat of government regulations. Then the District Regulations and District Regulations were continued so that the community prepared all the requirements, then submitted them to the district government, then registered with the governor, after which they were submitted to the Ministry of Home Affairs. Second, for the regitation of Kampong Adat in Riau province, only five and five years later, namely Regional Regulation Number 2 Year 2019, even though this Regional Regulation is very much needed for the process of preparing Kampong Adat.

Third, Kampong Adat has not been enthusiastically welcomed by the tradition community, this can be seen from the implementation of the material preparation meeting for approval from the Ministry of Home Affairs which is held once a year. However, there are many requirements that must be met. Especially the requirement for a map of the tradition area which is in contact with many interests.

The findings above show that the determination of the Kampong Adat comes from the interests of the parties to optimize hidden power through the commodification of 
tradition. Thus, the ratification of Kampong Adat still takes a long time and extra breakthroughs so that Kampong Adat have benefits for the wider community, not just the elite.

\section{Conclusion}

This study concludes that there is a contestation of two actors, namely the government and companies and a contestation of values. The pattern of contestation is as follows, first, formal power with the company. The formal government issues Kampong Adat affirmative policies for traditional law communities. The government encourages the recognition of traditional legal communities and the recognition of tradition areas through Kampong Adat. The recognition of this tradition area affects the operations of the company's HGU in the tradition area. Second, the formal power turned into a hidden power of the company in contesting with the traditional legal community who wanted the Kampong Adat to be ratified immediately. The hidden power at the local, district and provincial levels is a tool for companies to win contestations with traditional law communities who want immediate approval of Kampong Adat from the ministry. Third, the contestation of values between the Sakai tradition and the malay tradition to be used as the basis for the Kampong Adat, and the contestation between the Sakai tradition and the immigrant community.

Fourth, formal power, hidden power and corporations commodify tradition as an economic, political and imaging tool. Village of exists but the concept of Kampong Adat is not empirically based, so it is difficult to formulate the concept of Kampong Adat itself.

The results of this study contribute to anthropology of policy, particularly in formulating affirmative policies for the recognition and protection of traditional legal communities. Affirmative policies are very much needed by traditional legal communities, but are placed in the right portion so that affirmative policies are not discriminatory against the majority community members in the Village of Minas Barat.

\section{Conflicts of Interest:}

The authors declare that there is no conflict of interest.

Acknowledgement:

We would like to thank AAI Pengda Riau, SKK Migas Sumbagut and PT Chevron Indonesia for funding this research and AAI Pengda Riau for guiding the research and writing of this book through the SKK Migas - KKKS Collaboration program with AAI Pengda Riau for Research and Writing. Final Project on the program "SKK Migas - KKKS and AAI Riau Pengda Collaboration for research and writing student final assignments."

\section{References}

Afrizal. (2012). Kontestasi Ruang: Tinjauan Sosiologis Terhadap Keadilan Ekologis, Jurnal Ilmu Sosial Mamangan, Edisi 1, Tahun I, Juli 2012, pg. 1 - 9

Achdian, A., Yulianti B.A. (2013). Jalan Baru Otonomi Desa: Mengembalikan Otonomi Masyarakat (Studi Kasus Bali, Sumatera Selatan dan Flores). Jakarta: Kemitraan 
Perpustakaan.

Alkadafi, M. A., Rusdi, R., Agusti, F. R., \& April, M. (2019). Kebijakan Penetapan Pemerintahan Kampung Adat Di Kabupaten Siak Provinsi Riau. Jurnal ElRiyasah, 10(1), 1-20.

Amady, R.E. (2014). Negara Orde Baru: Industrialiasi dan Masyarakat Lokal. Yogyakarta: Alif Gemilang Persada.

Asrida, W., Amin, R. M., \& Marta, A. (2018). Bentuk-Bentuk Kekuasaan dalam Pemanfaatan Tanah Ulayat di Kabupaten Kampar. Jurnal Ilmu Pemerintahan Nakhoda, 17(29), 39-49.

BPK RI. (2021, October 29). Database Peraturan. https://peraturan.bpk.go.id/Home/Details/167172/Peraturan Daerah-provriau-no- 2-tahun-2019, di downlod 12 Oktober 2021 pukul 22.45.

BPS Siak. (2021). Kecamatan Minas Dalam Angka 2021.

Peraturan Daerah Kabupaten Siak No 2 Tahun 2015 Tentang Penetapan Kampong Adat Di Kabupaten Siak, Bupati Siak (2015).

Gede, I. G. K., Wirga, I. W., \& Suryadi, I. G. I. (2017). Model pemberdayaan desa adat pada dua desa tujuan wisata di Bali. Jurnal Bisnis dan Kewirausahaan, 12(1 Maret), 62.

Gunawan, D. H., Achdian, A., \& Yulianto, B. A. (2013). Jalan Baru Otonomi Desa: Mengembalikan Otonomi Masyarakat. Jakarta: Kemitraan Perpustakaan

Haryono, D. (2017). Kajian Kritis Pembentukan Pemerintahan Kampung Adat di Kabupaten Siak. Melayunesia Law, 1(1), 12-31.

Marfuah, I. (2014). Hasil Study Konflik Masyarakat Suku Sakai Desa Minas Barat. Dokumen Resmi Perkumpulan Scale Up, tidak dipublikasi.

Purba, B. (2011). Pengakuan dan Perlindungan Hak-Hak Konstitusional Masyarakat Hukum Adat Suku Sakai (Studi Tentang Peraturan Hukum dan Implementasinya terhadap Kebijakan Pemerintah yang Menimbulkan Konflik Masyarakat Suku Sakai di Kabupaten Siak dan Kabupaten Bengkalis Provinsi Riau) (Doctoral dissertation, Universitas Islam Indonesia).

Prakoso, W. D. (2020). Penetapan Wilayah Adat dan Masyarakat Hukum Adat Desa Penyengat Kecamatan Sungai Apit Kabupaten Siak. Jurnal Hukum Respublica, 19(2), 12-28.

Romadhon, A. H., Harianti, I., Rohyana, N., \& Agustina, M. (2018). Dinamika Pranata Pemerintahan Desa Adat Dalam Dimensi Hukum Tata Negara. Jurnal Hukum Media Bhakti. Vol. 2, Number 2, Des 2018, Pg. 127 137

Rahayu, L. (2013). Problematika Penyelesaian Konflik Tanah Ulayat Masyarakat Tradition Di Kabupaten Kampar (Studi Kasus: Desa Gunung Sahilan Kecamatan Gunung Sahilan Kabupaten Kampar Tahun 2012-2013). JOM FISIP, 1(1), 1-14.

Setiawan, H., \& Zetra, A. (2018). Strengthening Authority of Indigenous Actors PostDetermination of Kampong Adat Status in Siak Districts. Jurnal Ilmu Sosial Mamangan, 8(2), 70-79. https://doi.org/10.22202/mamangan.2013

Zain, M. A., \& Siddiq, A. (2015). Pengakuan Atas Kedudukan Dan keberadaan Masyarakat Hukum Tradition (MHA) Pasca Dibentuknya Undang - Undang Nomor 6 tahun 2014 Tentang Desa. Jurnal Penelitian Hukum, 2, 63-76.

Vancil, D.L. (1993). Rhetoric and Argumentation, Allyn and Bacon, Boston. 